\title{
Statistical Variations and New Correlation Models to Predict the Mechanical Behavior and Ultimate Shear Strength of Gypsum Rock
}

https://doi.org/10.1515/eng-2018-0026

Received March 17, 2018; accepted April 26, 2018

\begin{abstract}
In this study, over 1000 data from the several research studies was used to characterize and compare the density, strengths, modulus, flexural strength, porosity and the ultimate shear strengths of the calcium rocks. The gypsum rock data were statistically analyzed, quantified and compared with the limestone rock data. The ranges of the densities for gypsum rock $\left(\mathrm{CaSO}_{4} \cdot 2 \mathrm{H}_{2} \mathrm{O}\right)$ and limestone rock $\left(\mathrm{CaCO}_{3}\right)$ were 2.10 to $2.83 \mathrm{gm} / \mathrm{cm}^{3}$ and 1.70 to $2.75 \mathrm{gm} / \mathrm{cm}^{3}$, respectively. The compressive and tensile strengths of the gypsum and limestone rocks varied from $2 \mathrm{MPa}$ to $250 \mathrm{MPa}$ and $1.8 \mathrm{MPa}$ to $25 \mathrm{MPa}$, respectively. Vipulanandan correlation model was effective in relating the modulus of elasticity, flexural strength, with the relevant strengths of the rocks. A new nonlinear Vipulanandan failure criterion was developed to better quantify the tensile strength, pure shear (cohesion) strength and predict the maximum shear strength limit with applied normal stress on the gypsum and limestone rocks. The prediction of the failure models for the two rock types was also compared to the Mohr-Coulomb failure model. The Vipulanandan failure model predicted the maximum shear strength limit was, as the Mohr-Coulomb failure model does not have a limit on the maximum shear strength. With the Vipulanandan failure model based on the available data, the maximum shear strengths predicted for the gypsum and limestone rocks were $64 \mathrm{MPa}$ and $114 \mathrm{MPa}$, respectively.
\end{abstract}

Keywords: Calcium rocks, Strength, Flexural strength, Failure model, Statistical analysis, Modeling

\footnotetext{
^Corresponding Author: Ahmed Mohammed: Faculty of Engineering, Department of Civil Engineering, University of Sulaimani, Iraq, Kurdistan Region, E-mail: ahmed.mohammed@univsul.edu.iq Wael Mahmood: Graduate Student, Department of Civil Engineering, University of Sulaimani, Iraq, Kurdistan Region
}

\section{Introduction}

For constructing of various types of infrastructures on the rocks, it is important to better quantify the mechanical properties and failure criteria for the rocks. Also for the hydraulic fracturing of rocks in a cost-effective way it is important to design the drilling and fracturing processes using the rock properties including the tensile strength and failure criteria. Mohr-Coulomb criteria is used to characterize the failure of the rocks, with over predicting the tensile strength and no limit on the maximum shear strength tolerance with the applied normal stress on the rocks (Singh et al. 2015). In addition, there is very limited property correlation in the literature for the rocks. Hence, there is a need for developing improved failure criteria and property correlations for the rocks (Omar 2017).

Gypsum rock is a soft, sulfate mineral composed of calcium sulfate dehydrate, with the chemical formula $\mathrm{CaSO}_{4} \cdot 2 \mathrm{H}_{2} \mathrm{O}$ and it covers more than $20 \%$ of the earth crust, seven million square kilometers of gypsum rock covering by highly soluble gypsum-bearing rocks (Dreybrodt et al., 2002). Gypsum is a soluble mineral that deposits from natural water because of evaporation. Gypsum can transform to anhydrite by losing water, or anhydrite can transform to gypsum by the addition of water (Salih 2013). Several studies on gypsum rock showed that it experiences the various problems due change in the physical and mechanical properties of gypsum rock due to the dissolution of gypsum, so there is a need for prediction the mechanical properties of such a problematic type of the rock, such as gypsum rock (Klimchouk, 1996; Johnson, 2005; Salih et.al. 2017).

Limestone is another sedimentary rock, composed mainly of skeletal fragments of marine organisms such as coral, forams and mollusks. Its major materials are the minerals calcite and aragonite, which are different crystal forms of calcium carbonate $\left(\mathrm{CaCO}_{3}\right)$ (Milliman et al. 2012; Abdelaali et al. 2013). The limestone was popular as a building stone, because of its regional availability, its mechanical properties, and its attractive appearance, 
and was used in many types of buildings. Also, limestone has been used in several types of constructions such as, concrete aggregate, asphalt pavement aggregate, asphalt surface treatments, road base, structural fill, railroad ballast, riprap and drainage and erosion control (Bednarik et al. 2014).

Uniaxial unconfined compressive strength (UCS), the most widely used parameter to evaluate rock strength, requires expensive and time-consuming testing with sample preparation (Karakus et al. 2005). Many researchers have introduced several empirical equations for determination of rock strength from simple physical properties. By means of such properties, rock strength may be determined in an easy, quick, and inexpensive manner during field investigations (Sabatakakis et al. 2008; Rajabzadeh et al. 2012). In rock engineering, most applied rock classification systems are based on mechanical parameters such as uniaxial unconfined compressive strength, tensile strength $\left(\sigma_{t}\right)$ and Young's modulus or deformability modulus (E) (Selçuk et al. 2016). Tensile strength and compression modulus are two important parameters in rock mechanics, and are used in the initiation and propagation of fractures in hydraulic fracture modeling (Meng and Pan 2007; Vipulanandan and Mohammed 2015a). The tensile strength was determined for two gypsum and limestone rocks using the standard test method for direct tensile strength from American Society of the International Association for Testing and Materials (ASTM) (Jensen 2016). The unconfined compressive strength (UCS) and angle of internal friction $(\varphi)$ of gypsum and limestone rocks are key parameters needed to address a range of geomechanical problems ranging from limiting wellbore instabilities during drilling, to assessing sanding potential and quantitatively constraining stress magnitudes using observations of wellbore failure (Moos et al., 2003; Zoback et al. 2003).

\subsection{Vipulanandan models}

The Vipulanandan correlation model has been used to predict the behavior of cement and polymer modified soils (Usluogullari et al. 2011). Vipulanandan et al. (2007-2015) used the relationship to represent the variation of in-situ vertical stress and logarithmic undrained shear strength of the soft marine and deltaic clays; the Vipulanandan rheological model was also used to predict the rheological properties with the electrical resistivity of nanoclay modified bentonite-drilling muds. For shear thinning fluids, the shear stress-shear strain-rate relationship is nonlinear with a limit of the maximum shear stress tolerance. Vipulanandan and Mohammed (2014) used the Vipulanandan rheological model to predict the maximum shear stress limit for the bentonite drilling mud modified with the polymer. Similar trends were observed in many other engineering and environmental applications and have been modeled using the Vipulanandan correlation and rheological models (Mohammed 2016 - 2017).

\subsection{Objectives}

The focus of this study was to develop relationships for the tensile strength, compressive modulus, and failure model for the gypsum and limestone rocks using over 1000 data collected from the literature. The specific topics of interest are as follows:

1. To qualify the statistical variation in the density, compressive strength, tensile, modulus of elasticity, flexural strength, and porosity of gypsum and limestone rocks.

2. To investigate and quantify the correlation relation between the compression strength and tensile strength of gypsum and limestone rocks using the Vipulanandan correlation model.

3. To investigate and quantify the correlation between the compressive modulus of elasticity, flexural strength, and porosity with compressive and tensile strengths respectively of gypsum and limestone rocks using the Vipulanandan correlation model.

4. Quantify the shear failure strength of the rocks using the new Vipulanandan failure model and compare the prediction to the Mohr-Coulomb failure model.

\section{Methods and materials}

\subsection{Data collection}

This study focused on the behavior of gypsum rock compared with limestone rock collected from several research studies (Swapnil et al. 2004; Vipulanandan et al. 2009; Nam et al 2010; Salih et al 2017). The properties of interest were density, compressive and tensile strengths, flexural strength, compressive modulus, porosity and shear strength of the gypsum and limestone rocks. The density study focused on the statistical distribution and the range of variation using 97 data on gypsum and 184 data on limestone. The number of data collected based on the properties of the rock was also a clear indicator of the interest in rock behavior around the world. 


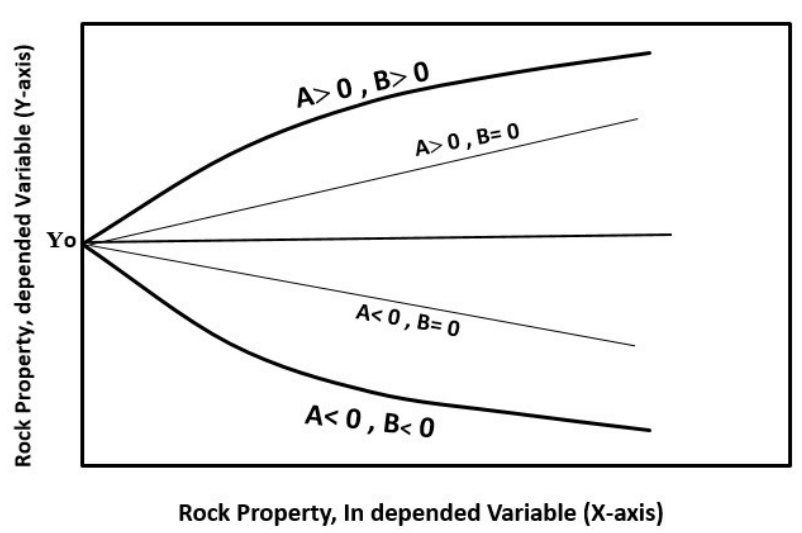

Figure 1: Vipulanandan mode the linear and nonlinear responses of rock

\subsection{Modeling}

\subsubsection{Vipulanandan correlation model}

The nonlinear correlation between the rock properties was investigated using the Vipulanandan correlation model for the gypsum and limestone rocks. Based on the inspection of the data collected the following relationship was selected:

$$
Y=Y_{o}+\frac{X}{\left(A+B^{\star} X\right)}
$$

where:

$\mathrm{X}=$ Depended variable (example: tensile strength, compressive modulus, porosity, flexural strength).

$\mathrm{Y}_{o}, \mathrm{~A}$ and $\mathrm{B}=$ model parameters depend on the material.

$\mathrm{Y}=$ Independent variable (example: compression strength).

Based on the data collected the correlations were either linear or nonlinear for the material properties of interest. As shown in Fig. 1, the relationship proposed in Eq. 1 can be used to represent various linear and nonlinear trends based on the values of the parameters $A$ and $B$. When parameters A and B are positive, the relationship was hyperbolic. The linear relationship is represented by Eq. 1 when $B$ = zero and A will take any value. When parameters $A$ and $B$ are negative, the inverse hyperbolic relationship is obtained.

\subsubsection{Mohr-Coulomb failure model}

The Mohr-Coulomb failure criterion represents the linear relationship between the shear strength of a rock and the applied normal stress on the failure plane. This relation is as follows:

$$
\tau=\tau_{o}+\sigma_{n} \tan \phi
$$

where $\tau$ is the shear strength, $\sigma_{n}$ is the normal stress, $\tau_{o}$ the pure shear strength (cohesion), and $\varphi$ is the slope of the internal friction angle.

From Eq. (3)

$$
\begin{gathered}
\frac{d \tau}{d \sigma_{n}}=\tan \varphi \\
\frac{d^{2} \tau}{d \sigma_{n}^{2}}=0
\end{gathered}
$$

when $\sigma_{n} \rightarrow \infty ; \tau=\infty$

Hence, Mohr-Coulomb failure model does not satisfy the upper limit condition for the shear strength tolerance of the materials.

\subsubsection{Vipulanandan new failure model}

Based on years of experience and reviewing the material shear strength versus applied normal stress is nonlinear, also there is limit to the maximum shear stress tolerance for all the materials, and hence following model and conditions are proposed:

$$
\tau=\tau_{o}+\frac{\sigma_{n}}{C+D^{\star} \sigma_{n}}
$$

$$
\begin{gathered}
\frac{d \tau}{d \sigma_{n}}=\frac{\left(C+D \sigma_{n}\right)-D \sigma n}{\left(C+D \sigma_{n}\right)^{2}}=\frac{C}{\left(C+D \sigma_{n}\right)^{2}}>0 \quad \Rightarrow C>0 \\
\frac{d^{2} \tau}{d \sigma_{n}^{2}}=-2\left(C+D \sigma_{n}\right)^{-3 \star C D}=\frac{-2 C D}{\left(C+D \sigma_{n}\right)^{3}}<0, \quad \Rightarrow D>0
\end{gathered}
$$

For pure tension when $\tau=0 \Rightarrow$

$$
\begin{gathered}
0=\tau_{o}+\frac{\sigma_{t}}{C+D^{\star} \sigma_{t}} \\
\sigma_{t}=\frac{-C \tau_{o}}{1+D \tau_{o}}
\end{gathered}
$$

Eq. (8) is similar to Eq. (1) in characterizing the tensile strength of rocks.

Also, when $\sigma_{n} \rightarrow \infty$

$$
\tau_{\infty}=\tau_{0}+1 \frac{1}{D}
$$

Hence, this model (Eq. 8) has a limit on the maximum shear stress the rocks will tolerate at relatively high normal stress.

\subsection{Comparison of model predictions}

In order to compare the model predictions statistical quantification such as coefficient of determination $\left(R^{2}\right)$ and the 
root mean square error (RMSE) were used and quantified as follows:

$$
\begin{aligned}
& R^{2}=\left(\frac{\sum_{i}\left(x_{i}-\bar{x}\right)\left(y_{i}-\bar{y}\right)}{\sqrt{\sum_{i}\left(x_{i}-\bar{x}\right)^{2}} \star \sqrt{\sum_{i}\left(y_{i}-\bar{y}\right)^{2}}}\right)^{2} \\
& R M S E=\sqrt{\frac{\sum_{i=1}^{n}\left(y_{i}-x_{i}\right)^{2}}{N}}
\end{aligned}
$$

where $y \mathbf{i}=$ experimental value; $x \mathbf{i}=$ predicted value from the model; $\bar{y}=$ mean of the actual test values; $\bar{x}=$ mean of calculated values and $\mathrm{N}$ is the number of data points.

\section{Results and analyses}

\subsection{Density $(\gamma)$}

Based on the 97 and 184 data for the gypsum and limestone rocks (Table 1, Table 2 and Table 3), the mean values of density were $2.27 \mathrm{gm} / \mathrm{cm}^{3}(\mathrm{~N}=97)$ and $2.49 \mathrm{gm} / \mathrm{cm}^{3}$ $(\mathrm{N}=184)$ respectively, as shown in Fig. 2 and Fig. 3. The histogram shows the relationship between the class of data (each class equal to mean value $+0.5 \mathrm{~g} / \mathrm{cm}^{3}$ ) and the number of times that range of value (frequency distribution of the data) was observed. In this study, the statistical details and the histograms were developed for each type of rock density data sets to identify the distribution as shown in Fig. 2 and 3, respectively.

\section{(i) Gypsum rock}

Based on 97 data for gypsum, the density $(\gamma)$ varied from $2.10 \mathrm{gm} / \mathrm{cm}^{3}$ to $2.83 \mathrm{gm} / \mathrm{cm}^{3}$ with the standard deviation of $0.02 \mathrm{gm} / \mathrm{cm}^{3}$ and coefficient of variation (COV) of $1.76 \%$ are summarized in Table 3. The histogram in Fig. 2

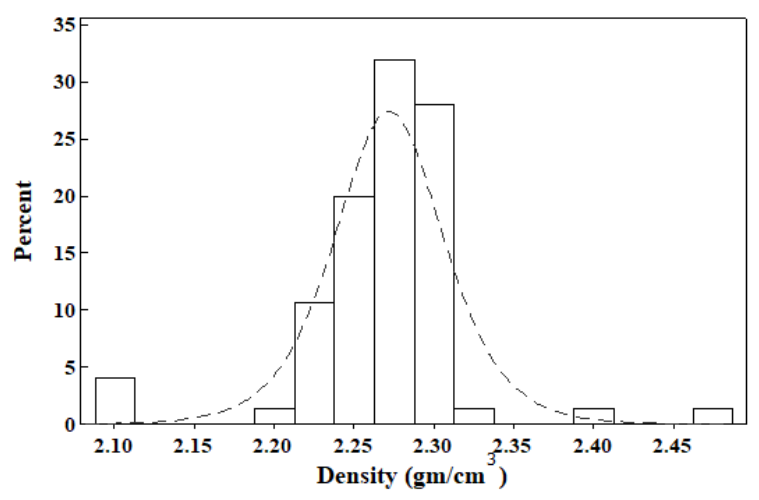

Figure 2: Largest Extreme Value Distribution of density for gypsum rock

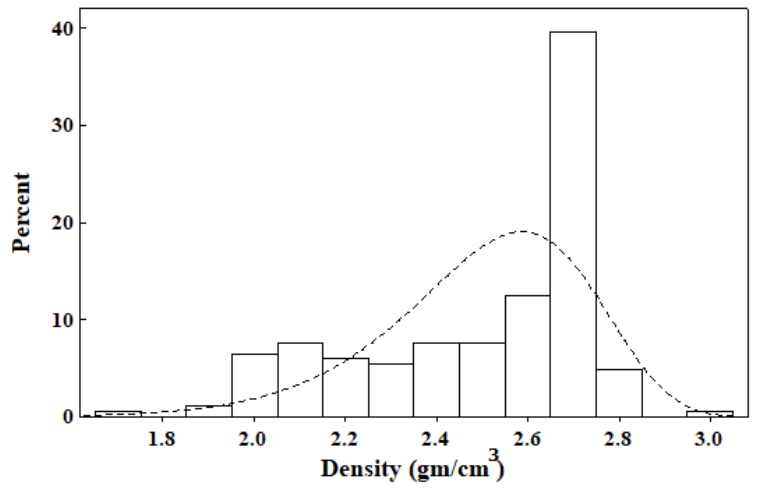

Figure 3: Weibull distribution for the density for Limestone

shows the number of data points in each range of density that were considered. Over $60 \%$ of the total of $\gamma$ was between $2.24 \mathrm{gm} / \mathrm{cm}^{3}$ and $2.32 \mathrm{gm} / \mathrm{cm}^{3}$. Different distribution tests for the densities for gypsum were performed. Based on the Anderson-Darling statistic (AD) and P-value (hypothesis testing), largest extreme value distribution for the densities for gypsum was observed, as shown in Fig. 2.

\section{(ii) Limestone}

A total of 184 data for limestone was analyzed and it varied from $1.71 \mathrm{gm} / \mathrm{cm}^{3}$ to $2.75 \mathrm{gm} / \mathrm{cm}^{3}$ with the standard deviation of $0.26 \mathrm{gm} / \mathrm{cm}^{3}$ and coefficient of variation (COV) of $10.4 \%$ are summarized in Table 3. The histogram (Fig. 3) showed almost $77 \%$ of the total $\gamma$ was between $2.3 \mathrm{gm} / \mathrm{cm}^{3}$ and $2.6 \mathrm{gm} / \mathrm{cm}^{3}$. More than $40 \%$ of the total of $\gamma$ was $2.7 \mathrm{gm} / \mathrm{cm}^{3}$. Different distribution tests for the densities of gypsum were performed. Based on the Anderson-Darling statistic (AD) and P-value (hypothesis testing), Weibull distribution for the densities for gypsum was observed and are shown in Fig. 3.

\subsection{Strength properties}

\subsubsection{Compressive strength $\left(\sigma_{c}\right)$}

Based on the 97 and 184 data of the gypsum and limestone rocks collected from literature (Table 1, 2 and 3), the compressive strength data for gypsum varied from $2 \mathrm{MPa}$ to $43 \mathrm{MPa}$ with a mean of $18.3 \mathrm{MPa}$, the standard deviation of $10 \mathrm{MPa}$ and coefficient of variation (COV) of $55 \%$ as summarized in Table 3. Based on the 184 compressive strength for limestone data (Table 3), it varied from 6.0 MPa to $250 \mathrm{MPa}$ with a mean of $68.4 \mathrm{MPa}$, the standard deviation of $36.6 \mathrm{MPa}$ and coefficient of variation (COV) of $53.5 \%$, as summarized in Table 3. 
Table 1: Summary of gypsum rock properties

\begin{tabular}{|c|c|c|c|c|c|c|c|c|c|}
\hline Reference & Location & $\begin{array}{l}\text { Density } \\
\left(\mathrm{gm} / \mathrm{cm}^{3}\right)\end{array}$ & $\begin{array}{c}\text { Tensile } \\
\text { Strength } \\
, \sigma_{t} \\
(\mathrm{MPa})\end{array}$ & $\begin{array}{l}\text { Compressive } \\
\text { Strength, } \sigma_{c} \\
(\mathrm{MPa})\end{array}$ & $\begin{array}{l}\text { Flexural } \\
\text { Strength, } \\
\sigma_{\mathrm{f}}(\mathrm{MPa})\end{array}$ & $\begin{array}{l}\text { Shear } \\
\text { Strength, } \\
\tau(\mathrm{MPa})\end{array}$ & $\begin{array}{l}\text { Elastic } \\
\text { Modulus, } \\
\text { E (GPa) }\end{array}$ & $\begin{array}{l}\text { Flexural } \\
\text { Strength, } \\
\sigma_{\mathrm{f}}(\mathrm{MPa})\end{array}$ & $\begin{array}{c}\text { Porosity, } \\
\text { n (\%) }\end{array}$ \\
\hline Bell (1981) & UK & - & - & - & - & - & - & - & $3.4-5.3$ \\
\hline $\begin{array}{l}\text { Singh et al. } \\
\text { (1987) }\end{array}$ & - & - & $1.8-2.3$ & $26-33$ & - & & $15.8-30$ & - & $0.9-2.9$ \\
\hline $\begin{array}{l}\text { Chen } \\
\text { (1989) }\end{array}$ & USA & - & - & - & - & - & - & - & - \\
\hline \multicolumn{10}{|l|}{ Papadopou } \\
\hline $\begin{array}{c}\text {-los et al. } \\
\text { (1994) }\end{array}$ & Greece & - & - & $4-12$ & - & & $0.7-3$ & - & - \\
\hline $\begin{array}{c}\text { Başpınar et } \\
\text { al. (2011) }\end{array}$ & Turkey & - & - & $2.4-5.2$ & $1.14-2.5$ & & $0.9-1.3$ & - & - \\
\hline $\begin{array}{l}\text { Heidari et } \\
\text { al. (2012) }\end{array}$ & Iran & - & $3.5-5.5$ & $3.8-30$ & - & & - & - & - \\
\hline $\begin{array}{l}\text { Liang et al. } \\
\text { (2012) }\end{array}$ & - & - & - & $8-14$ & - & $0.5-34$ & $3-8.1$ & - & - \\
\hline $\begin{array}{l}\text { Salih } \\
(2013)\end{array}$ & Iraq & $2.1-2.31$ & - & $2.3-43.2$ & $0.6-10.1$ & & - & $1.2-2.6$ & - \\
\hline $\begin{array}{l}\text { Selçuk et } \\
\text { al. (2015) }\end{array}$ & Turkey & $2.3-2.4$ & - & $14-19$ & - & & - & - & - \\
\hline $\begin{array}{l}\text { Meng et al. } \\
\quad(2007)\end{array}$ & China & - & - & - & - & - & - & - & $0.9-2.7$ \\
\hline $\begin{array}{c}\text { Yin et al. } \\
\text { (2017) }\end{array}$ & China & $2.4-2.83$ & - & $12.8-34$ & - & & $10-26$ & - & $6.6-8.1$ \\
\hline $\begin{array}{l}\text { Salih et al. } \\
\text { (2017) }\end{array}$ & Iraq & $1.8-2.78$ & - & $2-20$ & - & & $0.8-5$ & $1.4-3.4$ & - \\
\hline Remark & $\begin{array}{c}7 \\
\text { countries }\end{array}$ & $\begin{array}{c}\text { Varied } \\
\text { between } \\
2.1 \text { to } 2.83\end{array}$ & $\begin{array}{c}\text { Varied } \\
\text { between } \\
1.8 \text { to } 5.5 \\
\mathrm{MPa}\end{array}$ & $\begin{array}{c}\text { Varied } \\
\text { between } 2 \text { to } \\
43.2 \mathrm{MPa}\end{array}$ & $\begin{array}{c}\text { Varied } \\
\text { between } \\
0.6 \text { to } \\
10.1 \mathrm{MPa}\end{array}$ & $\begin{array}{c}\text { Varied } \\
\text { between } \\
0.5 \text { to } 34 \\
\mathrm{MPa}\end{array}$ & $\begin{array}{c}\text { Varied } \\
\text { between } \\
0.7 \text { to } 30 \\
\text { GPa }\end{array}$ & $\begin{array}{l}\text { Varied } \\
\text { between } 1.2 \\
\text { to } 3.4 \mathrm{MPa}\end{array}$ & $\begin{array}{c}\text { Varied } \\
\text { between } \\
0.92 \text { to } \\
8.1 \%\end{array}$ \\
\hline
\end{tabular}

\subsubsection{Tensile strength $\left(\sigma_{t}\right)$}

With 85 and 96 data of the gypsum and limestone rocks (Table 1, 2 and 3), the tensile strength data for gypsum varied from 1.8 MPa to 5.5 MPa with a mean of 3.5 MPa, the standard deviation of $1.18 \mathrm{MPa}$ and coefficient of variation (COV) of $34.2 \%$ as summarized in Table 3. From the 96 tensile strength data for limestone, it varied from $1.6 \mathrm{MPa}$ to $25 \mathrm{MPa}$ with a mean of $6.5 \mathrm{MPa}$, standard deviation of $1.5 \mathrm{MPa}$ and coefficient of variation (COV) of $23.1 \%$ as summarized in Table 3.

\subsubsection{Compressive modulus (E)}

Based on the 64 and 107 data of the gypsum and limestone rocks (Table 1, 2 and 3), the compressive modulus data for gypsum varied from $0.7 \mathrm{GPa}$ to $30 \mathrm{GPa}$ with a mean of $1.9 \mathrm{GPa}$, the standard deviation of $1.2 \mathrm{GPa}$ and coefficient of variation (COV) of $61.4 \%$ as summarized in Table 3. Depending on 107 compressive modulus data for limestone, the data varied from 7.0 GPa to $70 \mathrm{GPa}$ with a mean of $25.0 \mathrm{GPa}$, the standard deviation of $11.65 \mathrm{GPa}$ and coefficient of variation (COV) of $46.6 \%$ as summarized in Table 3. 
Table 2: Summary of limestone rock properties

\begin{tabular}{|c|c|c|c|c|c|c|c|c|}
\hline Reference & Location & $\begin{array}{c}\text { Density } \\
\left(\mathrm{gm} / \mathrm{cm}^{3}\right)\end{array}$ & $\begin{array}{c}\text { Tensile } \\
\text { Strength, } \\
\sigma_{\mathrm{t}}(\mathrm{MPa})\end{array}$ & $\begin{array}{l}\text { Compressive } \\
\text { Strength, } \sigma_{\mathrm{c}} \\
(\mathrm{MPa})\end{array}$ & $\begin{array}{c}\text { Shear } \\
\text { Strength, } \\
\tau(\mathrm{MPa})\end{array}$ & $\begin{array}{c}\text { Compression } \\
\text { Modulus, E } \\
\text { (GPa) }\end{array}$ & $\begin{array}{l}\text { Flexural } \\
\text { Strength, } \sigma_{f} \\
(\mathrm{MPa})\end{array}$ & $\begin{array}{c}\text { Porosity, n } \\
\text { (\%) }\end{array}$ \\
\hline $\begin{array}{l}\text { Schmidt } \\
(1976)\end{array}$ & USA & - & $4.6-5.78$ & - & - & $29-34.4$ & & - \\
\hline $\begin{array}{l}\text { Sachpazis } \\
\text { (1990) }\end{array}$ & Greek & - & - & 83-102 & - & $26-47$ & & - \\
\hline $\begin{array}{l}\text { Tugrul et al. } \\
\text { (1999) }\end{array}$ & Turkey & $2.5-2.67$ & - & $84-126$ & $10-40$ & $21.6-50.4$ & & - \\
\hline $\begin{array}{l}\text { Katz et al. } \\
(2000)\end{array}$ & USA & $2.07-2.7$ & - & $32-95$ & - & $12-39$ & & - \\
\hline $\begin{array}{l}\text { Kahraman } \\
\text { (2007) }\end{array}$ & Turkey & $2.67-2.69$ & - & $75-124$ & - & & & - \\
\hline $\begin{array}{l}\text { Fjar et al. } \\
(2008)\end{array}$ & USA & $\begin{array}{c}2.67- \\
2.72\end{array}$ & $6-25$ & $30-250$ & - & $20-70$ & & - \\
\hline Zhang (2002) & Sweden & - & $2.65-10.1$ & - & - & - & & - \\
\hline $\begin{array}{l}\text { Sarno et al. } \\
\text { (2009) }\end{array}$ & USA & $1.9-2.2$ & - & - & - & - & - & - \\
\hline $\begin{array}{l}\text { Aoki et al. } \\
\text { (2008) }\end{array}$ & Japan & $2.3-2.8$ & - & $22-203$ & - & - & - & - \\
\hline Heap (2009) & UK & - & - & - & $22-39$ & - & - & - \\
\hline $\begin{array}{l}\text { Guimin et al. } \\
\text { (2012) }\end{array}$ & China & - & - & - & 5-12 & - & - & - \\
\hline $\begin{array}{l}\text { Richard et al. } \\
\text { (2012) }\end{array}$ & USA & - & - & 6-193 & - & - & - & - \\
\hline $\begin{array}{l}\text { Rajabzadeh et } \\
\text { al. (2012) }\end{array}$ & Iran & $2.31-2.72$ & $5-14$ & $33-102$ & - & $7.0-17.7$ & - & $0.4-0.6$ \\
\hline $\begin{array}{l}\text { Ozturk et al. } \\
\text { (2013) }\end{array}$ & Turkey & - & - & $42-175$ & - & - & - & - \\
\hline $\begin{array}{l}\text { Okewale et al. } \\
\text { (2013) }\end{array}$ & Nigeria & $2.64-2.75$ & $1.65-3.3$ & $59.4-68.6$ & - & - & - & - \\
\hline $\begin{array}{l}\text { Kurtulus et al. } \\
\text { (2015) }\end{array}$ & Turkey & $1.8-2.35$ & $3.9-7.8$ & - & - & $38-64$ & - & - \\
\hline $\begin{array}{l}\text { Momeni et al. } \\
\text { (2015) }\end{array}$ & Malaysia & $2.57-2.71$ & - & $26-73.4$ & - & & - & - \\
\hline $\begin{array}{l}\text { Parent et al. } \\
\text { (2015) }\end{array}$ & France & $1.71-2.46$ & - & $53-98$ & - & $8.3-40.4$ & - & $0.2-0.7$ \\
\hline $\begin{array}{l}\text { Tuncay et al. } \\
\text { (2016) }\end{array}$ & Turkey & $1.81-2.2$ & - & - & - & - & $12-4$ & - \\
\hline $\begin{array}{l}\text { Akram at al. } \\
\text { (2017) }\end{array}$ & Pakistan & - & - & $36.5-63$ & - & & - & - \\
\hline $\begin{array}{l}\text { Salih et al. } \\
\text { (2017) }\end{array}$ & Iraq & $2.66-2.73$ & - & $28-200$ & - & $13.5-41.5$ & - & - \\
\hline Remark & $\begin{array}{c}13 \\
\text { countries }\end{array}$ & $\begin{array}{l}\text { Varied } \\
\text { between } \\
1.71 \text { to } 2.75 \\
\mathrm{gm} / \mathrm{cm}^{3}\end{array}$ & $\begin{array}{l}\text { Varied } \\
\text { between } \\
1.65 \text { to } 25 \\
\mathrm{MPa}\end{array}$ & $\begin{array}{l}\text { Varied between } \\
6 \text { to } 250 \mathrm{MPa}\end{array}$ & $\begin{array}{l}\text { Varied } \\
\text { between } 5 \\
\text { to } 40 \mathrm{MPa}\end{array}$ & $\begin{array}{l}\text { Varied between } 7 \\
\text { to } 70 \mathrm{GPa}\end{array}$ & $\begin{array}{l}\text { Varied between } \\
0.027 \text { to } 2 \\
\text { MPa. } \mathrm{m}^{0.5}\end{array}$ & $\begin{array}{l}\text { Varied } \\
\text { between 0.2- } \\
0.7 \%\end{array}$ \\
\hline
\end{tabular}

\subsubsection{Flexural strength $\left(\sigma_{f}\right)$}

From the 26 and 21 data of the gypsum and limestone rocks (Table 1, 2 and 3), the flexural strength data for gypsum varied from 1.2 MPa to $3.4 \mathrm{MPa}$ with a mean of $21.2 \mathrm{MPa}$, the standard deviation of $0.51 \mathrm{MPa}$ and coefficient of variation (COV) of 3.9\% as summarized in Table 3. Based on 21 flexural strength data for limestone, the data varied from $4 \mathrm{MPa}$ to $12 \mathrm{MPa}$ with a mean of $8.1 \mathrm{MPa}$, the standard de- 
Table 3: Statistical variation of rock properties

\begin{tabular}{|c|c|c|c|c|c|c|c|}
\hline & $\begin{array}{c}\text { Statistical } \\
\text { Parameters }\end{array}$ & $\begin{array}{c}\text { Density } \\
\left(\mathrm{gm} / \mathrm{cm}^{3}\right)\end{array}$ & $\begin{array}{l}\text { Compressive } \\
\text { Strength, } \sigma_{\mathrm{c}} \\
(\mathrm{MPa})\end{array}$ & $\begin{array}{l}\text { Tensile } \\
\text { Strength, } \\
\sigma_{\mathrm{t}}(\mathrm{MPa})\end{array}$ & $\begin{array}{c}\text { Compression } \\
\text { Modulus, E } \\
(\mathrm{GPa})\end{array}$ & $\begin{array}{l}\text { Flexural } \\
\text { Strength, } \sigma_{\mathrm{f}} \\
(\mathrm{MPa})\end{array}$ & $\begin{array}{c}\text { Porosity, } \\
\text { n (\%) }\end{array}$ \\
\hline \multirow{5}{*}{$\sum_{0}^{\Xi}$} & No. of Data & 97 & 97 & 85 & 64 & 19 & 26 \\
\hline & Range & $2.10-2.83$ & $2-43$ & $1.8-5.5$ & $0.7-30$ & $1.2-3.4$ & $0.92-8$ \\
\hline & Mean $(\mu)$ & 2.27 & 18.3 & 3.5 & 1.9 & 2 & 3 \\
\hline & $\begin{array}{l}\text { Std. } \\
\text { Deviation }(\sigma)\end{array}$ & 0.02 & 10 & 1.18 & 1.2 & 0.51 & 2.34 \\
\hline & COV (\%) & 1.76 & 55 & 34.2 & 61.4 & 3.92 & 77 \\
\hline \multirow{5}{*}{ 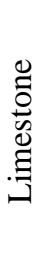 } & No. of Data & 184 & 184 & 96 & 107 & 21 & 35 \\
\hline & Range & $1.71-2.75$ & $6-250$ & $1.6-25$ & $7.0-70$ & 4-12 & $0.2-0.7$ \\
\hline & Mean $(\mu)$ & 2.49 & 68.4 & 6.5 & 25.00 & 8.1 & 0.38 \\
\hline & $\begin{array}{l}\text { Std. } \\
\text { Deviation }(\sigma)\end{array}$ & 0.26 & 36.6 & 1.5 & 11.65 & 2.30 & 0.135 \\
\hline & COV (\%) & 10.4 & 53.5 & 23.1 & 46.6 & 28.3 & 35 \\
\hline
\end{tabular}

viation of $2.30 \mathrm{MPa}$ and coefficient of variation (COV) of 28.3\% as summarized in Table 3.

\subsubsection{Porosity (n \%)}

Based on the 26 and 35 data of the gypsum and limestone rocks (Table 1, 2 and 3), the porosity data for gypsum varied from $0.92 \%$ to $8 \%$ with a mean of $3 \%$, the standard deviation of $2.34 \%$ and coefficient of variation (COV) of $77 \%$ as summarized in Table 3. Depending on 35 porosity data for limestone, the data varied from $0.2 \%$ to $0.7 \%$ with a mean of $0.38 \%$, the standard deviation of $0.135 \%$ and coefficient of variation (COV) of 35\% as summarized in Table 3.

\subsection{Property correlations}

\section{(a) The relationship between compressive strength $\left(\sigma_{c}\right)$ and density $(\gamma)$ \\ (i) Gypsum}

Total of 86 gypsum data were used (Table 4) to investigate the correlation between the density $(\gamma)$ and compressive strength $\left(\sigma_{c}\right)$ using Eq. 1, as shown in Fig. 4(a). With the Vipulanandan correlation model (Eq. 1) the model parameters $\mathrm{Y}_{0}, \mathrm{~A}, \mathrm{~B}$, coefficient of determination $\left(\mathrm{R}^{2}\right)$ and root mean square error (RMSE) were 411, 0.005, 0, 0.94 and $0.811 \mathrm{MPa}$ respectively as summarized in Table 4 .

\section{(ii) Limestone}

Based on 86 limestone data (Table 3), no direct correlation was observed between the density $(\gamma)$ and compressive strength $\left(\sigma_{c}\right)$ as shown in Fig. 4(b).

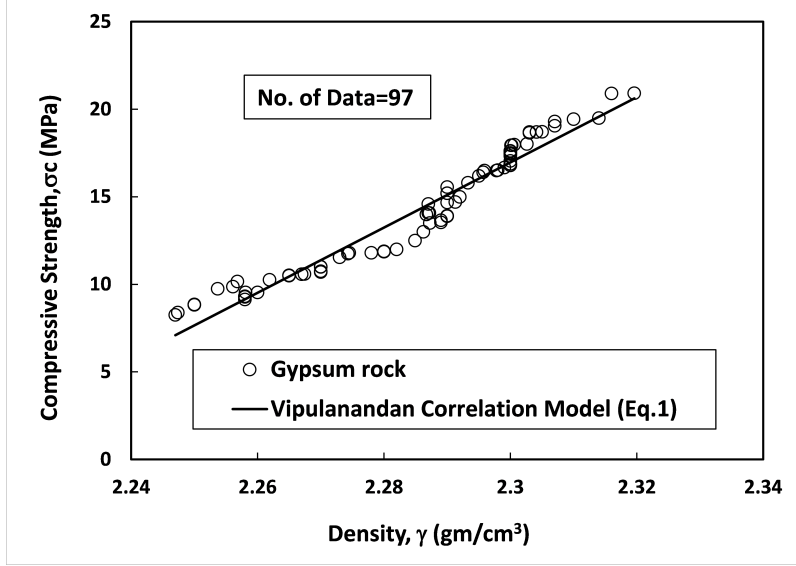

(a)

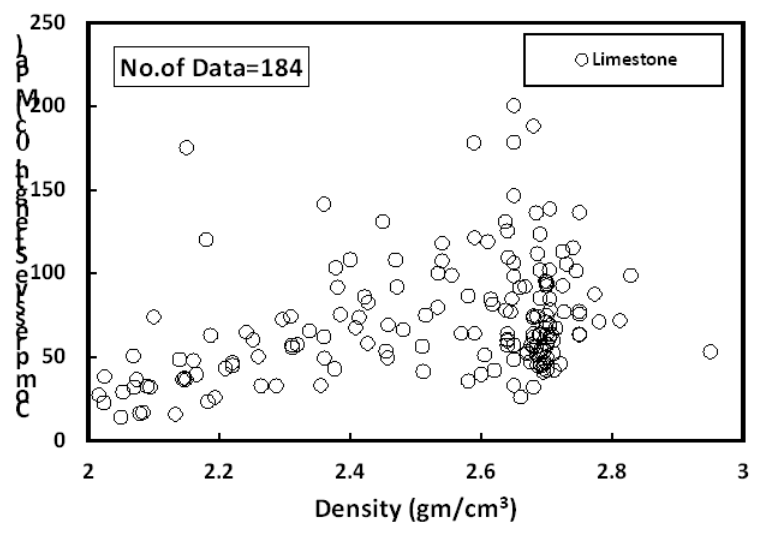

(b)

Figure 4: Variation of compressive strength and density of (a) gypsum and (b) limestone 
Table 4: Model parameters for physical and mechanical properties relationship of rocks

\begin{tabular}{|c|c|c|c|c|c|c|c|c|c|}
\hline \multirow[b]{2}{*}{$\begin{array}{c}\text { depended } \\
\text { Variable (Y- } \\
\text { axis) }\end{array}$} & \multicolumn{9}{|c|}{ Vipulanandan correlation model (Eq.1) } \\
\hline & $\begin{array}{l}\text { In depended } \\
\text { Variable (X- } \\
\text { axis) } \\
\end{array}$ & $\begin{array}{l}\text { Type of } \\
\text { rock }\end{array}$ & $Y_{0}$ & A & $\mathrm{B}$ & RMSE & $\mathrm{R}^{2}$ & $\begin{array}{l}\text { No. of } \\
\text { Data }\end{array}$ & $\begin{array}{l}\text { Fig. } \\
\text { No. }\end{array}$ \\
\hline $\begin{array}{l}\text { Compressive } \\
\text { Strength, } \sigma_{c}\end{array}$ & $\begin{array}{l}\text { Density, } \gamma \\
\left(\mathrm{gm} / \mathrm{cm}^{3}\right)\end{array}$ & Gypsum & 411 & 0.005 & 0.0 & 0.811 & 0.94 & 86 & $4(a)$ \\
\hline$(\mathrm{MPa})$ & & Limestone & 回 & - & - & - & - & 186 & $4(b)$ \\
\hline Tensile & Compressive & Gypsum & 0 & 2.88 & 0.0 & 0.11 & 0.99 & 86 & $5(a)$ \\
\hline $\begin{array}{l}\text { Strength, } \sigma_{\mathrm{t}} \\
(\mathrm{MPa})\end{array}$ & $\begin{array}{l}\text { Strength, } \sigma_{\mathrm{c}} \\
(\mathrm{MPa})\end{array}$ & Limestone & 0.0 & 2.16 & 0.11 & 0.65 & 0.80 & 96 & 5 (b) \\
\hline Compression & Compressive & Gypsum & 目 & 2.30 & 0.0 & 0.051 & 0.97 & 52 & $6(\mathrm{a})$ \\
\hline $\begin{array}{l}\text { Modulus, E } \\
\text { (GPa) }\end{array}$ & $\begin{array}{l}\text { Strength, } \sigma_{c} \\
(\mathrm{MPa})\end{array}$ & Limestone & 0.30 & 3.0 & 0.004 & 5.50 & 0.80 & 107 & $6(\mathrm{~b})$ \\
\hline Flexural & Compressive & Gypsum & 目 & 14.2 & 0 & 0.08 & 0.97 & 192 & 7 (a) \\
\hline $\begin{array}{l}\text { Strength, } \sigma_{\mathrm{f}} \\
(\mathrm{MPa})\end{array}$ & $\begin{array}{l}\text { Strength, } \sigma_{\mathrm{c}} \\
(\mathrm{MPa})\end{array}$ & Limestone & 0.75 & 17.3 & 0.02 & 0.94 & 0.83 & 21 & 7 (b) \\
\hline Porosity, n & Compressive & Gypsum & 12.3 & 0.87 & 0.05 & 0.32 & 0.98 & 26 & $8(a)$ \\
\hline (\%) & $\begin{array}{l}\text { Strength, } \sigma_{\mathrm{c}} \\
(\mathrm{MPa})\end{array}$ & Limestone & 6.0 & 0.17 & 0.611 & 0.103 & 0.94 & 35 & $8(b)$ \\
\hline
\end{tabular}

(b) The relationship between tensile strength $\left(\sigma_{t}\right)$ and compressive strength $\left(\sigma_{c}\right)$

\section{(i) Gypsum}

Total of 86 gypsum data were used (Table 4) to investigate the correlation between the tensile strength $\left(\sigma_{t}\right)$ and compressive strength $\left(\sigma_{c}\right)$ using Eq. 1 as shown in Fig. 5(a). With the Vipulanandan correlation model (Eq.1) the model parameters $\mathrm{Y}_{o}, \mathrm{~A}, \mathrm{~B}$, the coefficient of determination $\left(\mathrm{R}^{2}\right)$ and root mean square error (RMSE) were $0,2.88,0,0.99$ and $0.11 \mathrm{MPa}$ respectively as summarized in Table 4.

\section{(ii) Limestone}

Based on 96 limestone data (Table 4) and the property correlation was investigated using Model 1. With the Vipulanandan correlation model (Eq. 1) the model parameters $\mathrm{Y}_{o}, \mathrm{~A}, \mathrm{~B}$, the coefficient of determination $\left(\mathrm{R}^{2}\right)$ and root mean square error (RMSE) were 0, 2.16, 0.11, 0.80 and $0.65 \mathrm{MPa}$ respectively as summarized in Table 4. With the increase in $\sigma_{c}$ of the limestone rock, the $\sigma_{t}$ increased from 1.8 to 8.5 when the rock compressive strength increased to 200 MPa as shown in Fig. 5(b).

(c) The relationship between compressive strength $\left(\sigma_{c}\right)$ and compressive modulus (E)

\section{(i) Gypsum}

Using 64 gypsum data (Table 4), the variation of $\sigma_{c}$ with $\mathrm{E}$ of the gypsum rock was represented using the Vipulanandan correlation model relationship (Eq. 1) and the model parameters $\mathrm{Y}_{o}, \mathrm{~A}, \mathrm{~B}$, coefficient of determination $\left(\mathrm{R}^{2}\right)$ and root mean square error (RMSE) were $3.1 \mathrm{GPa}, 2.30$, 0, 0.97 and $0.051 \mathrm{GPa}$ respectively as summarized in Table 4. With the increase in $\sigma_{c}$ of rocks, the E linearly increased as shown in Fig. 6(a).

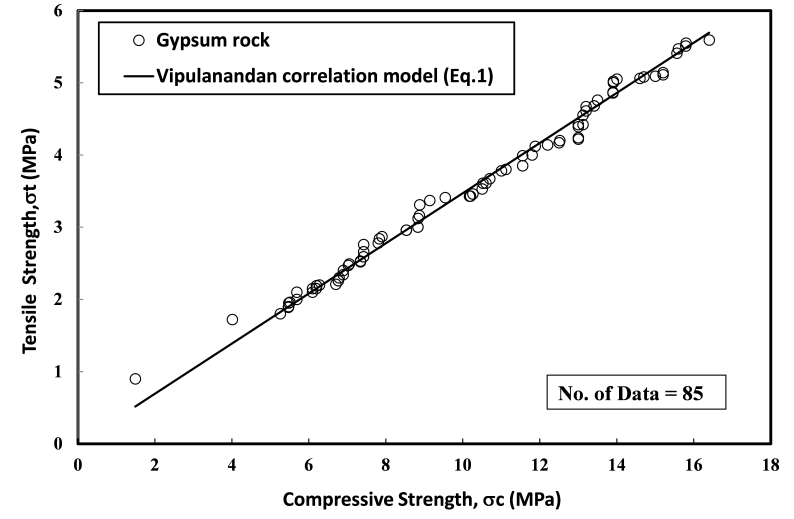

(a)

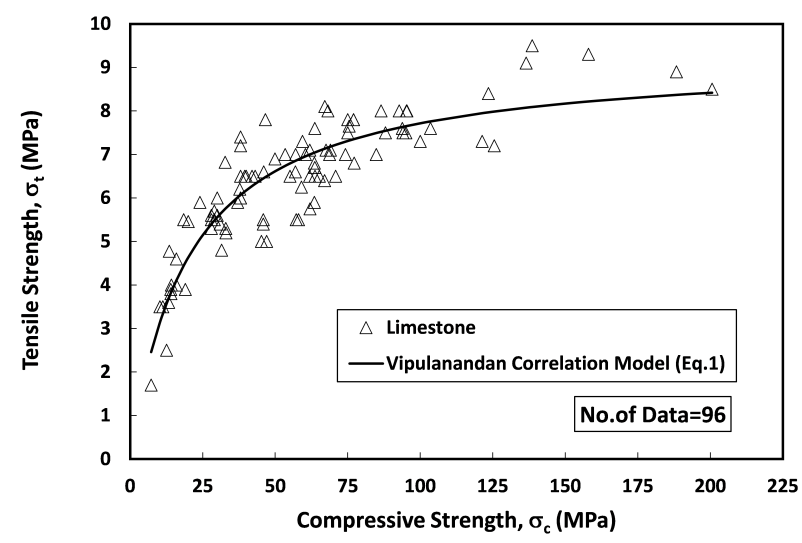

(b)

Figure 5: Variation of tensile and compressive strength of (a) gypsum and (b) limestone 


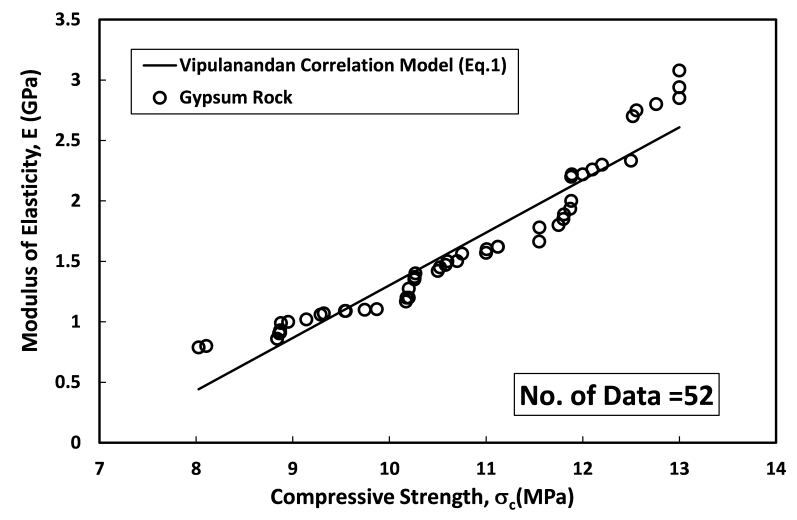

(a)

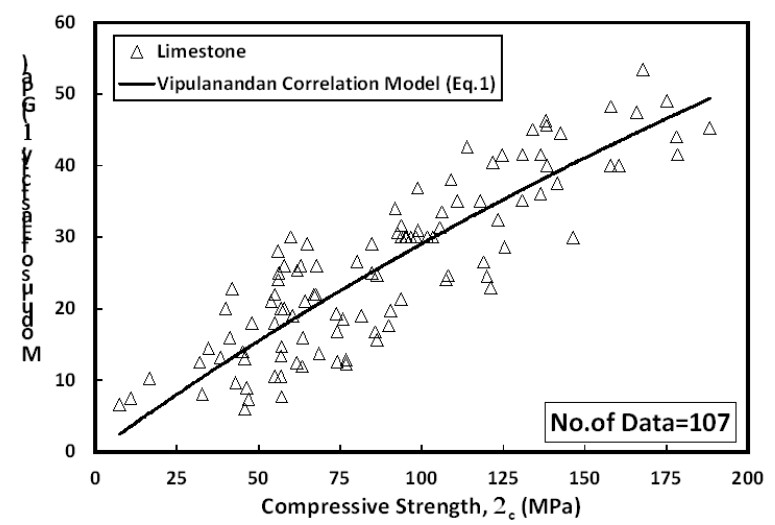

(b)

Figure 6: Variation of modulus of elasticity with compressive strength of (a) gypsum and (b) limestone

\section{(ii) Limestone}

Based on the total of 107 limestone data were collected from various research studies (Table 3 ) and the property correlation was investigated. With increasing of $\sigma_{c}$ of the limestone rock, the E nonlinearly increased as shown in Fig. 6(b). The change in the $\sigma_{c}$ with $\mathrm{E}$ for the rock was represented using the Vipulanandan correlation model relationship (Eq. 1) and the model parameters $\mathrm{Y}_{o}, \mathrm{~A}, \mathrm{~B}$, the coefficient of determination $\left(\mathrm{R}^{2}\right)$ and root mean square error (RMSE) were $0.30 \mathrm{GPa}, 3.0,0.004 \mathrm{GPa}^{-1}, 0.80$ and $5.50 \mathrm{GPa}$ respectively as summarized in Table 4.

(d) The relationship between compressive strength $\left(\sigma_{c}\right)$ and flexural strength $\left(\sigma_{f}\right)$

\section{(i) Gypsum}

Total of 19 gypsum data (Table 3) was used for the property correlation study. With increasing in $\sigma_{c}$ of the rock, the $\sigma_{f}$ increased as shown in Fig. 7(a). The variation of $\mathrm{n}$ with the $\sigma_{f}$ for the gypsum rock was represented using the Vipulanandan correlation model relationship (Eq. 1) and the model parameters $\mathrm{Y}_{o}, \mathrm{~A}, \mathrm{~B}$, the coefficient of de- termination $\left(\mathrm{R}^{2}\right)$ and root mean square error (RMSE) were $0.62,14.2,0,0.97$ and $0.08 \mathrm{MPa}$ respectively as summarized in Table 4.

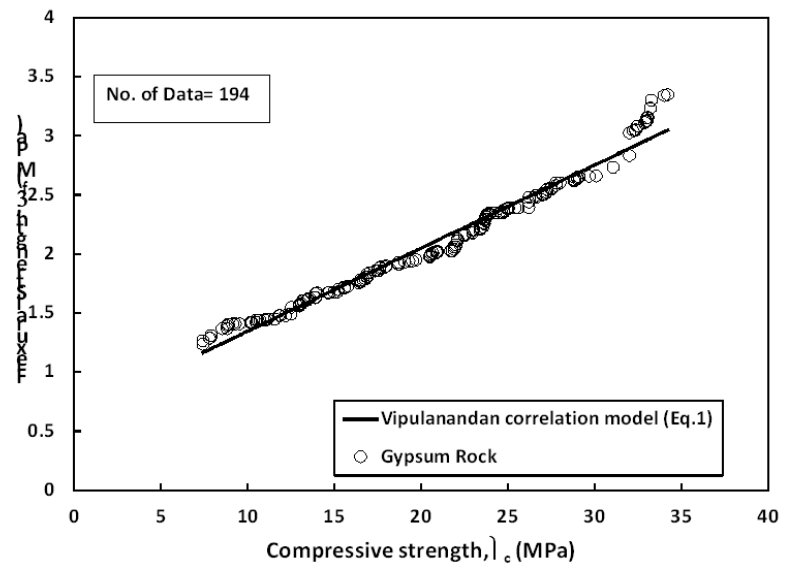

(a)

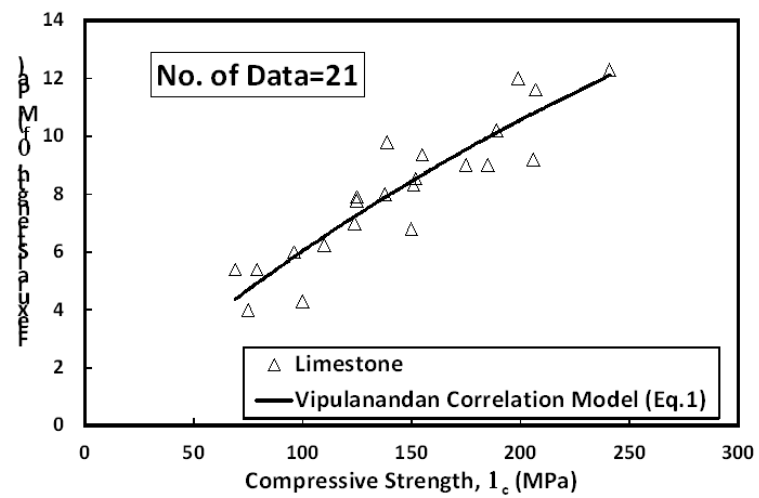

(b)

Figure 7: Variation of compressive and flexural strengths of (a) gypsum rock and (b) Limestone

\section{(ii) Limestone}

Based on the 21 limestone data (Table 3) collected from the literature, with increasing in $\sigma_{c}$ of the rock, the $\sigma_{f}$ also increased as shown in Fig. 7(b). The variation of $n$ with the $\sigma_{f}$ for the gypsum rock was represented using the Vipulanandan correlation model relationship (Eq. 1) and the model parameters $\mathrm{Y}_{o}, \mathrm{~A}, \mathrm{~B}$, the coefficient of determination $\left(\mathrm{R}^{2}\right)$ and root mean square error (RMSE) were $0.75,17.3$, $0.02,0.83$ and $0.94 \mathrm{MPa}$ respectively as summarized in Table 4.

(e) The relationship between compressive strength $\left(\sigma_{c}\right)$ and porosity (n)

\section{(i) Gypsum}

Total of 26 gypsum data (Table 3) was used for the property correlation study. With increasing in $\sigma_{c}$ of the 
rock, the porosity nonlinearly decreased as shown in Fig. 8(a). The variation of $\mathrm{n}$ with the $\sigma_{c}$ for the gypsum rock was represented using the Vipulanandan correlation model relationship (Eq. 1) and the model parameters $\mathrm{Y}_{o}$, $\mathrm{A}, \mathrm{B}$, the coefficient of determination $\left(\mathrm{R}^{2}\right)$ and root mean square error (RMSE) were 12.3\%, 0.87, 0.05, 0.98 and 0.32 $\%$ respectively as summarized in Table 4 .

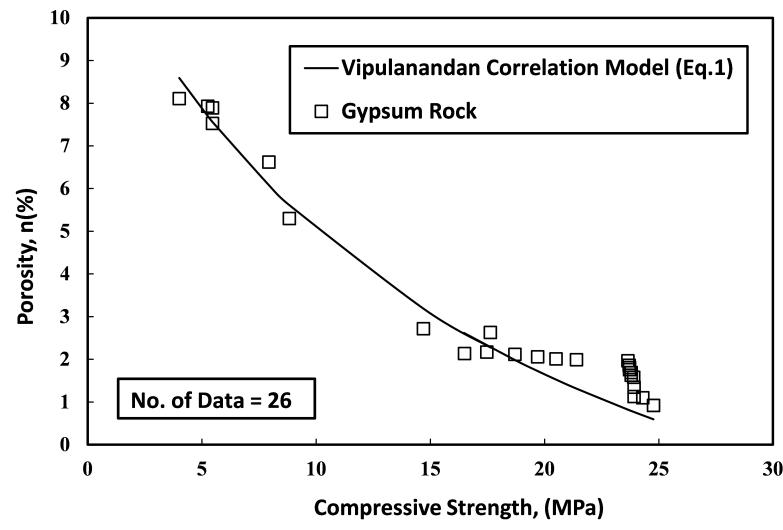

(a)

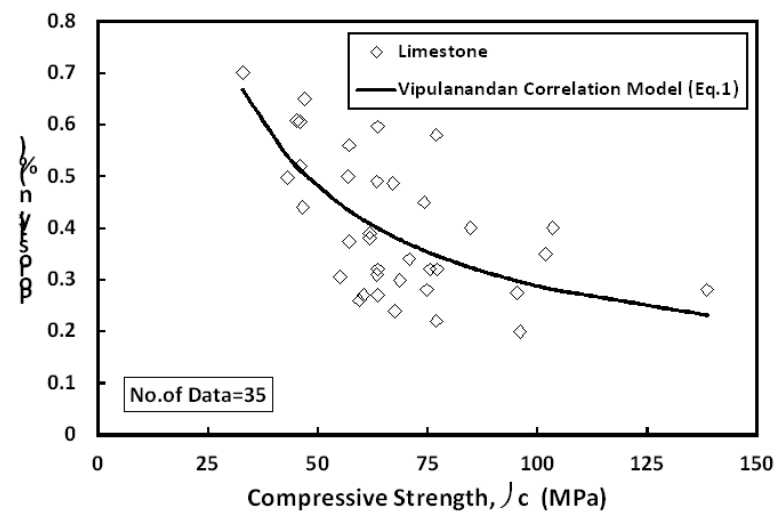

(b)

Figure 8: Variation of porosity with compressive strengths (a) gypsum and (b) limestone

\section{(ii) Limestone}

Based on the 35 limestone data (Table 3) collected from the literature, with increasing in $\sigma_{c}$ of the rock, the porosity nonlinearly decreased as shown in Fig. 8(b). The variation of $\mathrm{n}$ with the $\sigma_{c}$ for the gypsum rock was represented using the Vipulanandan correlation model relationship (Eq. 1) and the model parameters $\mathrm{Y}_{o}, \mathrm{~A}, \mathrm{~B}$, the coefficient of determination $\left(\mathrm{R}^{2}\right)$ and root mean square error (RMSE) were $6 \%, 0.17,0.611,0.94$ and $0.103 \%$ respectively as summarized in Table 4.

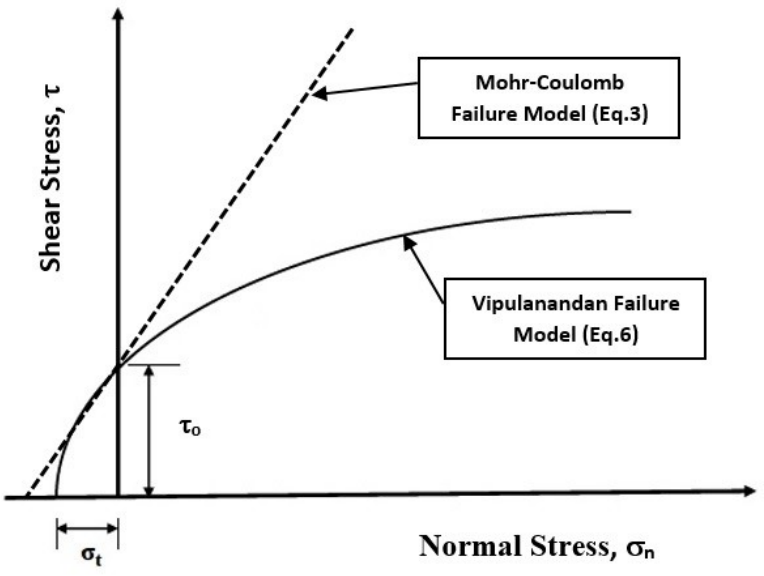

Figure 9: Vipulanandan failure mode compared to Mohr-Coulomb model

\subsection{Shear stress-normal stress failure models}

Shear stress-normal stress relationships were predicted using the Vipulanandan failure model and compared with the Mohr-Coulomb failure model as shown in Fig. 9.

\subsubsection{Mohr-Coulomb failure model}

\section{(a) Gypsum}

The failure behavior of gypsum was modeled with the Mohr-Coulomb failure criteria (Eq. (2)) using 113 data as shown in Fig. ??(a). The coefficient of determination $\left(\mathrm{R}^{2}\right)$ and root mean square of error (RMSE) were 0.80 and 2.7 MPa respectively as summarized in Table 5. The cohesion $\left(\tau_{o}\right)$, the angle of internal friction $(\varphi)$ and tensile strength $\left(\sigma_{t}\right)$ of the gypsum rock were $6.2 \mathrm{MPa}, 33^{\circ}$ and 4.6 MPa respectively as summarized in Table 5 .

\section{(b) Limestone}

The failure behavior of limestone was modeled with the Mohr-Coulomb failure criteria (Eq. (3)) using 44 data as shown in Fig. ??(b). The coefficient of determination $\left(\mathrm{R}^{2}\right)$ and root mean square of error (RMSE) were 0.97 and 3.4 MPa respectively as summarized in Table 5. The yield stress $\left(\tau_{o}\right)$, angle of internal friction $(\varphi)$ and tensile strength $\left(\sigma_{t}\right)$ of the limestone was $2.7 \mathrm{MPa}, 28^{\circ}$ and $5 \mathrm{MPa}$ respectively as summarized in Table 5 . 
Table 5: Model parameters for shear and normal stresses relationship of rocks

\begin{tabular}{|c|c|c|c|c|c|c|c|c|c|c|c|c|c|}
\hline \multicolumn{5}{|c|}{ Mohr-Coulomb model (Eq.2) } & \multicolumn{7}{|c|}{ Vipulanandan failure model (Eq.5) } & \multirow[b]{2}{*}{$\begin{array}{c}\text { No. } \\
\text { of } \\
\text { Data }\end{array}$} & \multirow[b]{2}{*}{$\begin{array}{l}\text { Fig. } \\
\text { No. }\end{array}$} \\
\hline $\begin{array}{c}\tau_{\mathrm{o}} \\
(\mathrm{MPa})\end{array}$ & $\phi\left({ }^{\circ}\right)$ & $\begin{array}{c}\sigma_{\mathrm{t}} \\
(\mathrm{MPa})\end{array}$ & $\begin{array}{l}\text { RMSE } \\
\text { (MPa) }\end{array}$ & $\mathrm{R}^{2}$ & $\begin{array}{c}\tau_{\mathrm{o}} \\
(\mathrm{MPa})\end{array}$ & $\begin{array}{c}\sigma_{\mathrm{t}} \\
(\mathrm{MPa})\end{array}$ & $\mathrm{C}$ & $\mathrm{D}$ & $\begin{array}{c}\tau_{\max .} \\
(\mathrm{MPa}) \\
\text { (Eq. 8) }\end{array}$ & $\begin{array}{l}\text { RMSE } \\
(\mathrm{MPa})\end{array}$ & $\mathrm{R}^{2}$ & & \\
\hline 6.2 & 33 & 4.6 & 2.7 & 0.80 & 5.1 & 5.0 & 1 & 0.016 & 64 & 1.89 & 0.80 & 113 & $10(a)$ \\
\hline 2.7 & 28 & 5.0 & 3.4 & 0.97 & 2.6 & 4.8 & 1.26 & 0.009 & 114 & 3.2 & 0.94 & 44 & $10(b)$ \\
\hline
\end{tabular}

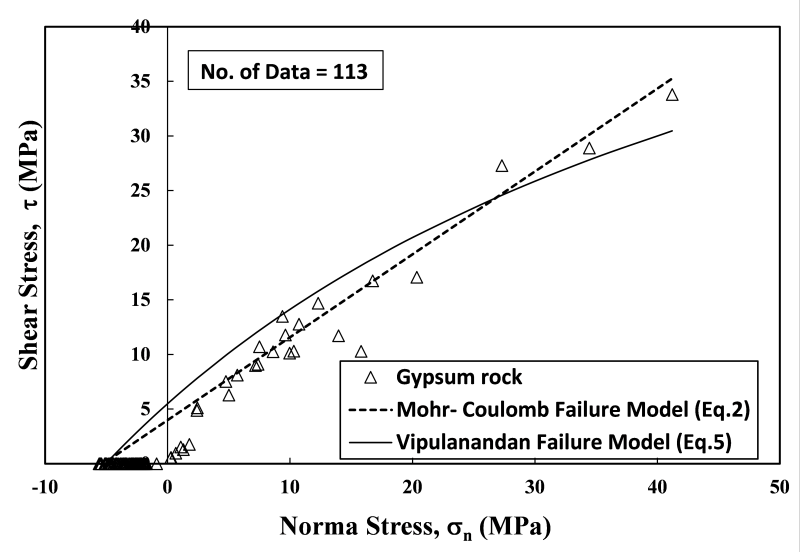

(a)

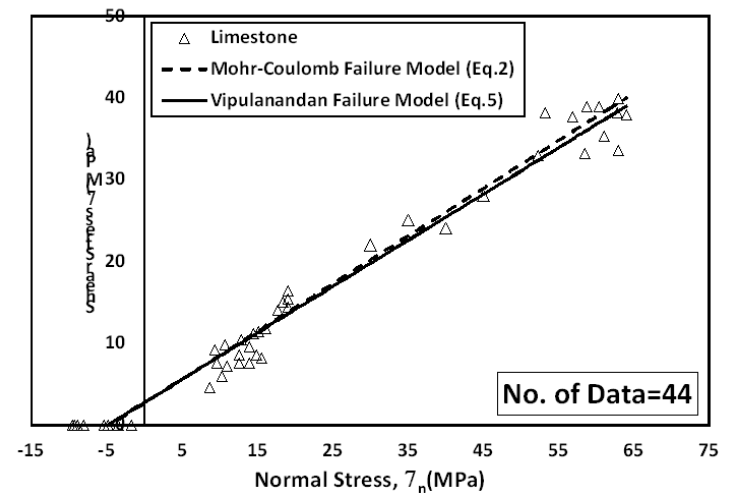

(b)

Figure 10: Variation of shear and normal stress of (a) gypsum and (b) limestone

\subsubsection{Vipulanandan failure model}

\section{(a) Gypsum}

The failure behavior of gypsum with 113 was predicted using the Vipulanandan failure model (Eq. (5)) as shown in Fig. ??(a). The coefficient of determination $\left(\mathrm{R}^{2}\right)$ and root mean square of error (RMSE) were 0.80 and $1.89 \mathrm{MPa}$ respectively as summarized in Table 5 . The cohesion $\left(\tau_{o}\right)$ and tensile strength $\left(\sigma_{t}\right)$ of the limestone was $5.1 \mathrm{MPa}$ and $5 \mathrm{MPa}$ respectively as summarized in Table 5 . The model parameters $\mathrm{C}$ and $\mathrm{D}$ for gypsum was 1 and 0.016 respectively as summarized in Table 5.

\section{(b) Limestone}

The failure behavior of limestone using 44 was modeled using the Vipulanandan failure model (Eq. ' (5)) as shown in Fig. ??(b). The coefficient of determinatio $\left(\mathrm{R}^{2}\right)$ and root mean square of error (RMSE) were 0.94 and 3.2 MPa respectively as summarized in Table 5 . The yield stress $\left(\tau_{o}\right)$ and tensile strength $\left(\sigma_{t}\right)$ of the limestone was 2.6 MPa and 4.8 MPa respectively as summarized in Table 5. The model parameter $\mathrm{C}$ and $\mathrm{D}$ for limestone was 1.26 and 0.01 respectively as summarized in Table 5 .

\subsection{Maximum shear strength $\left(\tau_{\text {max. }}\right)$}

Based on Eq. 8, the Vipulanandan failure model has a limit on the maximum shear stress ( $\tau_{\max }$ for the rocks at relatively high normal stress. The $\tau_{\max }$ for gypsum and limestone rocks were $64 \mathrm{MPa}$ and $114 \mathrm{MPa}$ respectively as summarized in Table 5.

\section{Conclusions}

The focus of this study was to characterize and compare the calcium rock behavior based on the density, properties, flexural strength and failure strength. Based on over 1000 data collected data from the literature studies, analytical models were developed, and the following conclusions are advanced:

1. The statistical analyses clearly indicated the variation in the density, tensile strength, compressive strength, compressive modulus and flexural strength of the two types of rocks investigated. The variation in the properties were quantified based on the coefficient of variation.

2. There was a positive correlation between the compressive strength with tensile strength and compressive modulus of elasticity of the rocks using the Vipulanandan correlation model. 
3. The flexural strength of the rocks showed good correlation with the compressive strength of the rocks using the Vipulanandan correlation model.

4. The new Vipulanandan failure criterion predicted the failure of the rocks very well and the maximum shear strength for the rocks. The maximum shear stress $\left(\tau_{\max }\right)$ for gypsum and limestone rocks $64 \mathrm{MPa}$ and $114 \mathrm{MPa}$ respectively based on the data used in this study.

\section{List of symbols}

ASTM International Association for Testing and Materials

$\tau \quad$ (cohesion) shear strength

$\tau_{o} \quad$ Pure shear strength

$\varphi \quad$ Slope of the internal friction angle.

$\gamma \quad$ Density

COV coefficient of variation

AD Based on the Anderson-Darling statistic

$\mathrm{K}_{I} \quad$ Mode-1 Fracture toughness

$\mathrm{R}^{2}$ coefficient of determination

RMSE root mean square error

Acknowledgement: The Civil Engineering Department, University of Sulaimani, supported this study.

\section{References}

[1] Abdelaali, R., Abderrahim, B., Mohamed, B., Yves, G., Abderrahim, S., Mimoun, H., and Jamal, S. (2013). Prediction of porosity and density of calcarenite rocks from P-wave velocity measurements. International Journal of Geosciences.

[2] Akram, M. S., Farooq, S., Naeem, M., and Ghazi, S. (2017). Prediction of mechanical behaviour from mineralogical composition of Sakesar limestone, Central Salt Range, Pakistan. Bulletin of Engineering Geology and the Environment, 2(76), 601-615.

[3] Aoki, H., and Matsukura, Y. (2008). Estimating the unconfined compressive strength of intact rocks from Equotip hardness. Bulletin of Engineering Geology and the Environment, 67(1), 23-29.

[4] Başpınar, M. S. and E. Kahraman (2011). "Modifications in the properties of gypsum construction element via addition of expanded macroporous silica granules." Construction and Building materials 25(8): 3327-3333

[5] Bell, F.G. (1981) 'Geotechnical Properties of Some Evaporitic Rocks', Bulletin 24 of the International Association of Engineering Geology, pp. 137-144.

[6] Bednarik, M., Moshammer, B., Heinrich, M., Holzer, R., Laho, M., Rabeder, J., and Unterwurzacher, M. (2014). Engineering geological properties of Leitha Limestone from historical quarries in Burgenland and Styria, Austria. Engineering Geology, 176, 66-78.
[7] Chen, J. F. (1989). The development of the Cracked-Chevron-Notched Brazilian Disc method for rock fracture toughness measurement and tunnelling machine performance prediction.

[8] Dreybrodt, W., Romanov, D. and Gabrovsek, F. (2002) 'Karstification below Dam Sites: a Model of Increasing Leakage from Reservoirs', Environmental Geology, 42, pp. 518-524.

[9] Fjar, E., Holt, R. M., Raaen, A. M., Risnes, R., and Horsrud, P. (2008). Petroleum related rock mechanics (Vol. 53). Elsevier.

[10] Guimin, Z., Yinping, L., Chunhe, Y., and Wenjun, J. (2012). Relationship Between Shear Stress and Shear Strain at Post-peak Curves of Rocks Subjected to Direct Shear Tests. In 46th US Rock Mechanics/Geomechanics Symposium. American Rock Mechanics Association.

[11] Han, D. H., Nur, A., and Morgan, D. (1986). Effects of porosity and clay content on wave velocities in sandstones. Geophysics, 51(11), 2093-2107.

[12] Heidari, M., Khanlari, G. R., Kaveh, M. T., \& Kargarian, S. (2012). Predicting the uniaxial compressive and tensile strengths of gypsum rock by point load testing. Rock mechanics and rock engineering, 45(2), 265-273.

[13] Heap, M. J. (2009). Creep: Time dependent brittle deformation in rocks (Doctoral dissertation, UCL (University College London)), London, England.

[14] Johnson, K. S. (2005). Salt dissolution and subsidence or collapse caused by human activities. Reviews in Engineering Geology, 16, 101-110.

[15] Jensen, S. S. (2016). Experimental Study of Direct Tensile Strength in Sedimentary Rocks (Master's thesis, NTNU).

[16] Katz, O., Reches, Z., and Roegiers, J. C. (2000). Evaluation of mechanical rock properties using a Schmidt Hammer. International Journal of Rock Mechanics and Mining Sciences, 37(4), 723-728.

[17] Kahraman, S. (2007). The correlations between the saturated and dry P-wave velocity of rocks. Ultrasonics, 46(4), 341-348.

[18] Karakus, M., Kumral, M., and Kilic, O. (2005). Predicting elastic properties of intact rocks from index tests using multiple regression modelling. International Journal of Rock Mechanics and Mining Sciences, 42(2), 323-330.

[19] Klimchouk, A. (1996) 'The Dissolution and Conversion of Gypsum and Anhydrite' Int. J. Speleol., 25 (3-4), pp. 21-36.

[20] Kurtuluş, C., Sertçelik, F., and Sertçelik, I. (2016). Correlating physico-mechanical properties of intact rocks with P-wave velocity. Acta Geodaetica et Geophysica, 51(3), 571-582.

[21] Liang, W., Yang, X., Gao, H., Zhang, C., Zhao, Y., \& Dusseault, M. B. (2012). Experimental study of mechanical properties of gypsum soaked in brine. International Journal of Rock Mechanics and Mining Sciences, 53, 142-150

[22] Meng, Z., and Pan, J. (2007). Correlation between petrographic characteristics and failure duration in clastic rocks. Engineering geology, 89(3), 258-265.

[23] Milliman, J., Müller, G., and Förstner, F. (2012). Recent sedimentary carbonates: Part 1 marine carbonates. Springer Science and Business Media.

[24] Moos, D., Peska, P., Finkbeiner, T., and Zoback, M. (2003). Comprehensive wellbore stability analysis utilizing quantitative risk assessment. Journal of Petroleum Science and Engineering, 38(3), 97-109.

[25] Momeni, E., Armaghani, D. J., Hajihassani, M., and Amin, M. F. M. (2015). Prediction of uniaxial compressive strength of rock 
samples using hybrid particle swarm optimization-based artificial neural networks. Measurement, 60, 50-63.

[26] Mohammed, A. S., and Vipulanandan, C. (2014). Compressive and tensile behavior of polymer treated sulfate contaminated CL soil. Geotechnical and Geological Engineering, 32(1), 71-83.

[27] Mohammed, A., and Vipulanandan, C. (2015). Testing and modeling the short-term behavior of Lime and Fly Ash treated sulfate contaminated CL soil. Geotechnical and Geological Engineering, 33(4), 1099-1114.

[28] Mohammed, A. S. (2016). Effect of temperature on the rheological properties with shear stress limit of iron oxide nanoparticle modified bentonite-drilling muds. Egyptian Journal of Petroleum.

[29] Mohammed, A. S. (2017a). Electrical resistivity and rheological properties of sensing bentonite-drilling muds modified with lightweight polymer. Egyptian Journal of Petroleum.

[30] Mohammed, A. (2017 b). Vipulanandan model for the rheological properties with ultimate shear stress of oil well cement modified with nanoclay, DOI 10.1016/j.ejpe.2017.05.007.

[31] Mohammed, A. S. (2017 c). Property Correlations and Statistical Variations in the Geotechnical Properties of $(\mathrm{CH})$ Clay Soils. Geotechnical and Geological Engineering, 1-15.

[32] Nam, M. S., and Vipulanandan, C. (2010). Relationship between Texas Cone Penetrometer Tests and Axial Resistances of Drilled Shafts Socketed in Clay Shale and Limestone. Journal of Geotechnical and Geoenviromental Engineering, 136(8), 1161-1165.

[33] Omar, M. (2017). Empirical correlations for predicting strength properties of rocks-United Arab Emirates. International Journal of Geotechnical Engineering, 11(3), 248-261.

[34] Okewale, I. A., and Olaleye, B. M. Correlation of Strength Properties of Limestone Deposit in Ogun State, Nigeria with Penetration Rate Using Linear Regression Analysis for Engineering Applications.

[35] Ozturk, C. A., and Nasuf, E. (2013). Strength classification of rock material based on textural properties. Tunnelling and Underground Space Technology, 37, 45-54.

[36] Papadopoulos, Z., Kolaiti, E., \& Mourtzas, N. (1994). The effect of crystal size on geotechnical properties of Neogene gypsum in Crete. Quarterly Journal of Engineering Geology and Hydrogeology, 27(3), 267-273.

[37] Parent, T., Domede, N., Sellier, A., and Mouatt, L. (2015). Mechanical characterization of limestone from sound velocity measurement. International Journal of Rock Mechanics and Mining Sciences, 79, 149-156.

[38] Rajabzadeh, M. A., Moosavinasab, Z., and Rakhshandehroo, G. (2012). Effects of rock classes and porosity on the relation between uniaxial compressive strength and some rock properties for carbonate rocks. Rock mechanics and rock engineering, 45(1), 113-122.

[39] Richard, T., Dagrain, F., Poyol, E., and Detournay, E. (2012). Rock strength determination from scratch tests. Engineering Geology, 147, 91-100.

[40] Sachpazis, C. I. (1990). Correlating Schmidt hardness with compressive strength and Young's modulus of carbonate rocks. Bulletin of Engineering Geology and the Environment, 42(1), 75-83.

[41] Sabatakakis, N., Koukis, G., Tsiambaos, G., and Papanakli, S. (2008). Index properties and strength variation controlled by microstructure for sedimentary rocks. Engineering Geology, 97(1), 80-90.

[42] Sarno, A., Farah, R., Hudyma, N., and Hiltunen, D. R. (2009). Relationships between index and physical properties of weathered Ocala limestone. In 43rd US Rock Mechanics Symposium and 4th US-Canada Rock Mechanics Symposium. American Rock Mechanics Association.

[43] Salih, N. B. (2013). Stability of dams constructed on problematic substrates (Doctoral dissertation, Brunel University School of Engineering and Design PhD Theses).

[44] Salih, N., and Mohammed, A. (2017). Characterization and modeling of long-term stress-strain behavior of water confined pre-saturated gypsum rock in Kurdistan Region, Iraq. Rock mechanics and geotechnical engineering, 9 (5), 10.1016/j.jrmge.2017.03.009.

[45] Schmidt, R. A. (1976). Fracture-toughness testing of limestone. Experimental Mechanics, 16(5), 161-167.

[46] Selçuk, L., \& Kayabali, K. (2015). Evaluation of the unconfined compressive strength of rocks using nail guns. Engineering Geology, 195, 164-171.

[47] Selçuk, L., and Nar, A. (2016). Prediction of uniaxial compressive strength of intact rocks using ultrasonic pulse velocity and rebound-hammer number. Quarterly Journal of Engineering Geology and Hydrogeology, 49(1), 67-75,

[48] Singh, M. V., Chhabra, R., \& Abrol, I. P. (1987). Interactions between applications of gypsum and zinc sulphate on the yield and chemical composition of rice grown on an alkali soil. The Journal of Agricultural Science, 108(2), 275-279.

[49] Singh, M., Samadhiya, N. K., Kumar, A., Kumar, V., and Singh, B. (2015). A nonlinear criterion for triaxial strength of inherently anisotropic rocks. Rock Mechanics and Rock Engineering, 48(4), 1387-1405.

[50] Swapnil, K., Kim, Min-Gu and Vipulanandan, C. (2004) "Nondestructive Properties of Clay shale and Limestone in Dallas, Texas", Proceeding (CD), ARA/NARMS 04-559, American Rock Mechanics Association, Houston, Texas, June 6, 2004.

[51] Tiwari, R. P., and Rao, K. S. (2007). Response of an anisotropic rock mass under polyaxial stress state. Journal of materials in civil engineering, 19(5), 393-403.

[52] Tugrul, A., and Zarif, I. H. (2000). Engineering aspects of limestone weathering in Istanbul, Turkey. Bulletin of Engineering Geology and the Environment, 58(3), 191-206.

[53] Tuncay, E. B., Kilinçarslan, Ş., \& Yağmurlu, F. (2016). Investigation of Usability as Aggregate of Different Originated Rocks. In IOP Conference Series: Earth and Environmental Science (Vol. 44, No. 2, p. 022002). IOP Publishing.

[54] Usluogullari, O. F., and Vipulanandan, C. (2011). Stress-strain behavior and California bearing ratio of artificially cemented sand. Journal of Testing and Evaluation, 39(4), 1-9.

[55] Vipulanandan, C., Ahossin Guezo, Y. J., and Bilgin, Ö. (2007). Geotechnical properties of marine and deltaic soft clays. In Advances in Measurement and Modeling of Soil Behavior, ASCE, GSP 173, pp. 1-13.

[56] Vipulanandan, C. and Nam, E. (2009), "Drilled Shaft Socketed in Uncemented Clay Shale," Proceedings, Foundation Congress 2009, Contemporary Topics in Deep Foundations, ASCE, GSP 185, pp. 151-158.

[57] Vipulanandan, C., and Mohammed, A. S. (2014). Hyperbolic rheological model with shear stress limit for acrylamide 
polymer modified bentonite-drilling muds. Journal of Petroleum Science and Engineering, Vol. 122, 38-47.

[58] Vipulanandan, C., and Mohammed, A. S. (2015 a). Characterizing the Hydraulic Fracturing Fluid Modified with Nano Silica Proppant. AADE-15-NTCE-38, CD Proceeding, San Antonio, Texas, April 2015.

[59] Vipulanandan, C., and Mohammed, A. (2015 b) Effect of nanoclay on the electrical resistivity and rheological properties of smart and sensing bentonite drilling muds. Journal of Petroleum Science and Engineering, 130, 86-95.

[60] Vipulanandan, C., and Mohammed, A. (2015 c) XRD and TGA, Swelling and Compacted Properties of Polymer Treated Sulfate Contaminated CL Soil. Journal of Testing and Evaluation, 44(6), 2270-2284.

[61] Vipulanandan, C., and Mohammed, A. (2015 d) Smart cement modified with iron oxide nanoparticles to enhance the piezoresistive behavior and compressive strength for oil well applications. Smart Materials and Structures, 24(12), 125020.

[62] Vipulanandan, C., and Mohammed, A. (2015 e) Smart cement rheological and piezoresistive behavior for oil well applications. Journal of Petroleum Science and Engineering, 135, 50-58.

[63] Vipulanandan, C., and Mohammed, A. (2017a). Rheological Properties of Piezoresistive Smart Cement Slurry Modified With Iron-Oxide Nanoparticles for Oil-Well Applications. Journal of Testing and Evaluation, 45(6).
[64] Vipulanandan, C., Mohammed, A., and Samuel, R. G. (2017). Smart Bentonite Drilling Muds Modified with Iron Oxide Nanoparticles and Characterized Based on the Electrical Resistivity and Rheological Properties with Varying Magnetic Field Strengths and Temperatures. OTC-MS-270626.

[65] Yin, S., Zhou, W., Shan, Y., Ding, W., Xie, R., \& Guo, C. (2017). Assessment of the geostress field of deep-thick gypsum cap rocks: A case study of Paleogene Formation in the southwestern Tarim Basin, NW China. Journal of Petroleum Science and Engineering, 154, 76-90.

[66] You, M. (2015). Strength criterion for rocks under compressive-tensile stresses and its application. Journal of Rock Mechanics and Geotechnical Engineering, 7(4), 434-439

[67] Zhang, Z. X. (2002). An empirical relation between mode I fracture toughness and the tensile strength of rock. International Journal of Rock Mechanics and Mining Sciences, 39(3), 401-406.

[68] Zoback, M. D., Barton, C. A., Brudy, M., Castillo, D. A., Finkbeiner, T., Grollimund, B. R., and Wiprut, D. J. (2003). Determination of stress orientation and magnitude in deep wells. International Journal of Rock Mechanics and Mining Sciences, 40(7), 1049-1076. 